\begin{tabular}{|r|}
\hline ANGIELS \\
NEW PERSPECTUE55 \\
ANGLOPHINE WDRLD
\end{tabular}

\section{Angles}

New Perspectives on the Anglophone World

13 | 2021

The Torn Object

\title{
Improvisation, Blankness and Mesmerism: Mike Leggett and Ian Breakwell's Sheet and the Two Avant-Gardes
}

\section{Kieran Devaney}

\section{OpenEdition}

Journals

Electronic version

URL: https://journals.openedition.org/angles/4263

DOI: 10.4000/angles.4263

ISSN: 2274-2042

Publisher

Société des Anglicistes de l'Enseignement Supérieur

\section{Printed version}

Date of publication: 15 December 2021

\section{Electronic reference}

Kieran Devaney, "Improvisation, Blankness and Mesmerism: Mike Leggett and lan Breakwell's Sheet and the Two Avant-Gardes", Angles [Online], 13 | 2021, Online since 15 December 2021, connection on 29 December 2021. URL: http://journals.openedition.org/angles/4263; DOI: https://doi.org/10.4000/ angles. 4263

This text was automatically generated on 29 December 2021.

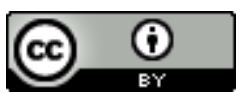

Angles est mise à disposition selon les termes de la Licence Creative Commons Attribution 4.0 International. 


\title{
Improvisation, Blankness and Mesmerism: Mike Leggett and Ian Breakwell's Sheet and the Two Avant-Gardes
}

\author{
Kieran Devaney
}

1 Mike Leggett and Ian Breakwell's film Sheet, made in 1970, is a conceptual film with a very simple concept: the filmmakers shot a square white sheet of fabric placed in a range of locations, indoors and outdoors, in the city and the countryside. Though little scholarship exists on Sheet, the enigmatic quality of the film and the sheet that gives it its name has given rise to a number of contrasting interpretations. Both Leggett and Breakwell were members of the London Film-makers Co-operative (LFMC), and the film was first shown in September 1970 at the National Film Theatre Underground Festival at the London New Arts Laboratory. The concerns that the LFMC filmmakers had around structure, the image, projection, and the material qualities of film, are present in Sheet, but there is also something else going on. The physical qualities of the sheet itself, how it can be crumpled, deformed, draped, stretched, its blankness, but also the way that it can occlude, interrupt and transform its environment, as well as its resemblance to the shroud, the ghost, the blank canvas and the screen onto which film is projected, cannot help but give rise to a view of the film which sees the sheet's presence as uncanny, a deeply ambivalent and unsettling object whose symbolism is unclear. The film invites a response that discerns a narrative, as well as one which is focussed on materiality and structure.

2 In Structural Film Anthology, filmmaker and theorist Peter Gidal writes:

An avant-garde film defined by its development towards increased materialism and materialist function does not represent or document anything. The film produces certain relations between segments. between what the camera is aimed at and the way that 'image' is presented. The dialectic of the film is established in that space of tension between materialist flatness, grain, light, movement, and the supposed 
reality that is represented. Consequently, a continual attempt to destroy the illusion is necessary (Gidal 1978: 1) period in which Sheet was made. For Gidal, avant-garde film is not representational, and the film must work towards illuminating the gap between the image on screen, which is merely a result of the coming together of materials and processes, and reality. But nonrepresentation is an ideal to be gestured towards through anti-representational practices, as Gidal acknowledges, a continual process rather than an absolute. Even here, while setting out the lineaments of what avant-garde film is, he is unable to avoid conceding a "supposed reality that is represented". There is an implicit politics in Gidal's commitment to destroying the illusion, moving away from the content-focus of most narrative and commercial films, which he sees as inducing passivity, and overidentification with certain characters and ideologies. Gidal wants the avant-garde film to actively engage the viewer, who participates, intervenes, and creates meaning during the film's projection.

This view of avant-garde film in general and of the LFMC more specifically has a certain austerity and self-reflexivity to it. More recent scholarship on the LFMC has sought to complicate that austerity and emphasise the diversity of approaches that were taken by filmmakers, as well as the ways in which narrative and representation inevitably intrude. For example, A.L. Rees writes that:

The purist, if not puritan, elements in the structural avant-garde were not their only feature, as time now shows. Seen today, their strict forms also have more playful ingredients. The 'room films' of the time are revealing and moving documents of typically spartan domestic space (Rees 2016).

Indeed, in Gidal's own films of the period, especially Condition of Illusion (1975) and Silent Partner (1977), one cannot help but pay attention to those domestic spaces, the books on the shelves, their titles, their bindings, typescripts, the objects on tables, the furniture and layout of the rooms (a similar experience to watching Stan Brakhage film interiors, or the 'diary' films of Jonas Mekas, one of proximity to the domestic, of attention to the materials and objects that people surround themselves with). As much as Gidal sought to avoid documentation and representation, they intrude, narrative intrudes.

Leggett and Breakwell seem to understand this tension between the structural and the narrative in Sheet. The formal, conceptual qualities of the film are the same qualities that invite a narrative reading, but the ambiguities of the central symbol of the film, the sheet, means that the film resists clear interpretation and allows for a multiplicity of views.

7 In the short document which accompanied a retrospective of the LFMC, 'Shoot Shoot Shoot: The First Decade of the London Film-Makers' Co-operative 1966-1976', Sheet is described in two very different ways. A letter sent anonymously to the filmmakers by an audience member had this response, which has been reprinted on several occasions to accompany screenings of the film:

Shrouding or hiding belong both to death as the mysterious unseen killer, and to the corpse. Sheet has all these feelings. The uncertainty and surprise: where will it appear next? The sheet appears in odd places, making familiar objects look strange and uncanny. The party goes on with everybody pretending it isn't there, embarrassed, ashamed of it, it is eventually kicked into a corner. This sums up our present approach to death. As the film proposes: the more we pretend it isn't there, 
the more it pursues us. Then, in the final sequence in the valley there seems to be a feeling of resolution. Perhaps that the earth will eventually claim us, but also gives us birth, growth, and protection. So, as we realize that the sheet and the valley go together, so the sheet can go off to a more bearable distance (Anon 1970).

This reading emphasises a narrative tension within the film, seeing the sheet as a symbol of death, one which appears in unexpected locations and infects them, rendering them uncanny, but which is also pervasive and implacable: the more we try to ignore it and cast it aside, the more it will pursue us. The sheet is the monster in a horror film, but also the victim, the corpse, simultaneously. Here also, the audience member sees the film as having a narrative progression, from the urban to the rural and natural, and gives an ecological, even spiritual slant to that progression, suggesting that an acceptance and proximity to nature will give us a deeper and healthier relationship to death.

'Shoot Shoot Shoot' offers two very different readings of the film, both of which foreground the film's structural, non-narrative qualities. The first, by curator Mark Webber, makes reference to the film's largely urban location:

Sheet develops from a conceptual basis and could be viewed as documentation of an event. The eponymous object is seen in different locations, making this one of the few experimental films that offer us incidental glimpses of London during this period (Webber 2014).

Webber's emphasis on the conceptual and on documentation seems to allow little room for the more expansive interpretation offered by the anonymous viewer of the film above, instead focussing on the qualities that characterise it as a structural film. Webber's comments are echoed in Roger Hammond's remarks about the film, written in 1972 for the LFMC catalogue:

Sheet is concerned with redefining boundaries, affirming that old Gestalten thing that elements in a field are always subordinated to the whole, the composition of it - an aggregate of episodes - is such that what finally emerged was a somewhat soft mesmeric movie, the repetitions and symmetries setting up moods in which one became immersed (Hammond 2002).

Hammond in particular seeks to bring the film into a highly structural, highly abstract register. For Hammond, the durational aspect of the film, its rhythm and repetition (or rather the accumulation of that repetition, what he calls the "aggregate") give the film an affective quality, capable of transfixing the viewer, inducing in them an altered state. In this view, rather than the sheet carrying the immense symbolic weight that it does according to the anonymous viewer, it rather functions as a unifying object. The boundaries that the film is concerned with redefining are, for Hammond, to do with a manner of viewing. The sheet is placed within the locations of the film, a consistent, though blank, element that, in its foreignness and the way that it transforms the environments it appears in, perversely necessitates a deeper engagement with those environments on the part of the viewer. The choice of the sheet as the focal object is crucial, not only its blankness, but also its malleability, the way that it appears in many different orientations, capable of occluding and deforming the landscape. For Hammond, this occlusion does not suggest a hidden presence, even a hidden character, as it does for the anonymous commentator, but instead a means of compelling the viewer to look again, more closely, at the environments of the film. But this looking is instinctive rather than cerebral, and is structural in its nature rather than focussed on 
any particular detail. The sheet as the focal object and the way in which Leggett and Breakwell film it induces the mesmeric quality that Hammond describes.

The two contrasting views of Sheet from Hammond, Mark Webber and from the anonymous viewer of the film, can be understood in terms of what Peter Wollen called "two distinct avant-gardes" (Wollen 1975). In the article, Wollen sets up a series of oppositions between these two distinct modes of avant-garde filmmaking, the first of which he associates with directors such as Jean-Luc Godard and Straub-Huillet, whose work remains rooted in narrative. Wollen sees this strand of the avant-garde as having a lineage in the Soviet directors of the 1920s, particularly Eisenstein, and who employ modernist techniques in their films to further their aesthetic or narrative aims. In Godard, Wollen recognises an extension of these techniques, such that he:

[...] takes the idea of formal conflict and struggle and translates it into a concept of conflict, not between the content of images, but between different codes and between signifier and signified (Wollen 1975)

For Wollen, this enables Godard to produce films which "investigate the whole process of signification out of which a world-view or an ideology is constructed" (Wollen 1975). Wollen sees part of the political work that Godard's films are doing, particularly his post-68 films, as being a consequence of that investigation and disruption.

Wollen's second avant-garde is identified with the co-op movement, and his analysis is similar to Peter Gidal's discussed above, though Wollen is much more circumspect about the value of this kind of filmmaking, and is concerned about the implications of its desire for purity:

The frontier reached by this avant-garde has been an ever-narrowing preoccupation with pure film, with film "about" film, a dissolution of signification into objecthood or tautology (Wollen 1975)

Much of Wollen's analysis in the article concerns the differences in culture, production, budgets, and audience as being distinguishing features between these two avantgardes. Straub-Huillet and Godard are much closer to commercial cinema, while the coop movement has its roots in the art world. For Wollen, what divides these two avantgardes is less ideology or even technique, but "more [...] the film-makers' frame of reference, the places from which they come and the culture to which they relate" (Wollen 1975). He concludes his article optimistically, hoping for a way to bring the two approaches together, a cross-fertilisation which would emphasise the cinema as what he calls, a "multiple system" (Wollen 1975) of image, sound and movement coming together to create new meaning. I would like to argue that Sheet can be seen as acting under some of the same impulses as Wollen at the conclusion of his article.

Earlier I noted A.L. Rees' view of Peter Gidal's 'room' films (as well as of similar films of the period from other directors, and I would include those moments in Sheet that occur in domestic spaces), and the way in which narrative enters into the space of those films through the objects in those rooms, how they are positioned, a certain sense of clutter or disorder (half-full glasses, notebooks and papers scattered across tables) that suggests that the film is taking place during the course of an ordinary day, or interrupting that day, rather than the space being one that has been designed or arranged for the film. Not only that, but the techniques used in those films, particularly the use of the handheld camera which, despite the discomfort felt by Gidal and others at the identification of the view of the camera with the view of a character, does at times suggest an invasion or interrogation of that space, which itself implies some 
sense of narrative. There is then a tension between narrative and anti-narrative which I think Sheet deliberately inserts itself into, but it's worth interrogating that further as a means of contextualising the film within the discourse of its time, and what the issue of narrative and anti-narrative meant for filmmakers at the time in the UK and elsewhere, and the way in which narrative and the political are intertwined in that discourse. In 1966, Annette Michelson published 'Film and the Radical Aspiration'. She identifies a nostalgia in filmmakers for a time when formal innovation and political content were effortlessly unified (the apotheosis of which is the early work of Eisenstein). This nostalgia is expressed in a lack, an inability to speak except as an admission of that inability. She writes:

The process of dissociation, the split between formal and political aspects of radical or revolutionary efforts was created, irremediably so - at least through our time. The result was either reaction or a sublimation of the revolutionary aspiration into a purely formal radicalism. The vestiges of the politically revolutionary experience and tradition are henceforth expressed in the form of nostalgia and frustration. Politically oriented art at its best became a chronicle of absence, of negation, an analysis of dissociation, and, in the best modernist tradition, a formal statement of the impossibility of discourse. (Michelson 1966: 413)

The split that Michelson identifies hangs heavy over the discourse that surrounds experimental filmmaking in the 1970s and seems to be felt particularly strongly by the writers and filmmakers of the London Filmmakers Cooperative. This accounts for the divergent responses to when Sheet was shown publicly. Filmmakers such as Peter Gidal contributed to this discourse both in their films and theoretical writings, and Gidal in particular sought to bring to bear a set of techniques in his films which anticipated and made use of the inevitable intrusion of narrative in a way that served his political and aesthetic principles in a way which took these principles to what can either be seen as their logical conclusion or a dead end. In his account of Gidal's work, D.N. Rodowick deems Gidal "ascetic" (Rodowick 1988: 141), and echoes Michelson in saying that, for Gidal,

[...] the "impossibility of history" becomes the impossibility of the political in film, if one means by that the positive transformation of social practices through which capitalist society maintains its hegemony. (Rodowick 1988: 140)

In Rodowick's view, Gidal pursues this impossibility; where A.L. Rees perceives the unwanted emergence of narrative into a non-narrative space, Gidal makes use of that tension, disrupting the naturalism of the camera's 'eye' and the progress of that narrative using uniform shot lengths, black leader, splice marks and varying focus. As Rodowick puts it:

[...] the history of cinema - its forms, meanings, and politics - are replayed, recirculated, and re-presented in every conventional, narrative film. [...] the object of antinarrative or the goal of a structural/materialist film practice is to perform the seemingly impossible task of defining, over and over and against the massive domination of film by narrative style and ideology, a series of negative strategies capable of derailing that history. (Rodowick 1988: 127)

Here, with the Sisyphean task of structural film as laid out by Rodowick, one thinks of the endless looping of Malcolm Le Grice's Berlin Horse, and of Rosalind Krauss's notion of grids in visual art, endless replicable, "the grid extends, in all directions, to infinity." (Krauss 1986: 18), and indeed of Michael Snow's Wavelength whose lengthy zoom takes the viewer through a domestic space, indeed through domestic drama, before arriving, albeit artificially, through a photograph, into the space of nature, a movement which 
Sheet also engages in. This is the context in which Sheet is produced, a context which it is aware of and engages with playfully.

At this point, it is important to say something about the production of the film, the way in which the locations and shots were chosen, and the way in which those choices contribute to both this sense of looking again. But it is also important to discuss the way in which the sheet functions in the film, and the sense of narrative and character that this gives rise to.

The filming took place, according to Joy L. Payne's book Reel Rebels: The London FilmMakers' Co-Operative 1966 to 1996, in:

[...] various locations including the Paris Metro, the New Arts Lab in London, Breakwell and Leggett's respective flats, Greenwich Park, the Goring Gap in Oxfordshire, Covent Garden, the streets of Smithfield, Bristol Arts Centre, Wantage in Somerset and in courtyards and on roof tops around the Barbican in London (Payne 2015)

23 As the anonymous commenter on the film notes, the film begins in an urban location and moves at its conclusion to a rural one, but that movement is not linear or straightforward. Rather, it consists of a circling back, moving through domestic spaces as well as public ones, empty and crowded streets, around and inside buildings. Several locations, particularly those located near Smithfield Market, where Breakwell was living at the time, reappear at various moments in the film. Mike Leggett writes that:

We took this $9 \mathrm{ft} \times \mathrm{ft}$ square sheet (with tabs on) to Paris because Ian had discovered the moving pavements at Montparnasse Bienven[ü]e Metro Station, and thought they needed filming with something in frame. So he did various things with the sheet while I filmed it. [...] The sheet would be placed within its environment (not a difficult place to find) and together they would be placed in their context within the film by setting up the camera, framing, panning, tilting, high speed, low speed, printing and editing... Few words were spoken, it was too obvious what needed to be done (Leggett ND)

The opening shots of the film contribute to a sense of the sheet as a presence, even a figure. The film begins with the sheet lying in a doorway, its edge draped around the curved wall of the building, suggesting a head and neck. This is followed by a fast pan along a street piled with bags and boxes of rubbish, the camera passing over the sheet, draped over a bollard, and draped in such a way, its lower edges trailing behind it like the train of a wedding dress, that it suggests a spectral figure, turned away from the camera, looking out past the edge of the frame, after which the camera pans down and away from it. That is, the viewer only glimpses the sheet, and like the first glimpse of a horror film monster, it is not immediately clear what was seen. We then see this same scene filmed from further away, the camera very briefly still, before it pans away from the sheet again, moving it to the side of the frame. Breakwell and Leggett then include a series of shots where the sheet is wrapped around the base of a lamppost. In the first and second of these, we see the sheet, and the camera returns to the bollard where the sheet was previously, revealing what was occluded, but it is as though the sheet has crossed the road and attached itself to another object. Its orientation no longer suggests a body, but something more like detritus that occupies the rest of the street, as though it has been blown there and got stuck. In the next shot of this sequence, the street is filmed in reverse angle, and shows a woman wearing a white sari walking towards the camera, her dress an echo of the sheet, which is behind her, still in position around the lamppost. Her sari blows against her in the wind, and she walks out of the frame. Breakwell and Leggett then very briefly - the shot lasts less than half a 
second - show the sheet at the far end of the road, lying on the ground, a small portion of it occluded by the end of a row of houses. Again, its orientation suggests a prone figure. In the final shot of this sequence, we return to the scene we saw previously of the woman in the sari, the street now empty except for the sheet and a large piece of white paper that blows around, another echo of the sheet. Again, the camera pans away and down.

These pans occur regularly in the film, and their shakiness and lack of uniformity, their tendency to veer, change speed and focus, are one way in which Breakwell and Leggett, remind the viewer of the presence of the camera and the hand that holds it. It is one way in which the film remains anti-illusionist in the sense defined by Gidal. The viewer is continually reminded that what they are viewing is mediated through the camera. That is, they are not seeing a sheet in an environment, the camera is seeing the environment and the viewer is seeing the image.

I am calling the above set of shots a complete sequence, as they all take place within the same small area and appear to be shot at the same time of day. To bundle them together and to suggest completeness is perhaps to attempt to force closure on the openness of the film. This location appears again several times in the film; for example, the same street is visible not long after this sequence, the sheet now lying in the middle of the road, entirely in a strip of sunlight that shines through a small gap in the buildings. And indeed, the shot featuring the woman in the sari is repeated very briefly later on. Behind the houses that curve away at the end of the road, one of the tower blocks on the Barbican Estate is visible. Breakwell and Leggett employ this circumlocutory structure which lends the film its lack of unity, its resistance to closure. But the two propositions that came from viewers of the film - the anonymous viewer's sense of a movement from the urban to the natural and of the sheet's spectral presence; and Roger Hammond's sense of the elements of the film being subordinated to its whole - seem to presuppose a structure which can be broken down and examined. Hammond's remarks in particular, with their reference to Gestalt theory, are intriguing because of the way in which they imply that the film is concerned with the relation between the part and the whole and the interdependence of objects captured within the frame of a film, even with the way in which the frame, and a sequence of frames, creates or seems to force a coherence and continuity between those objects. In relation to Gestalt theory, Ansel L. Woldt and Sarah M. Toman write:

Change anywhere in the field affects all subsystems of the field. The elements of the field are interdependent and subordinate to the whole and are regulated by their function in the whole [...] Any change in the complex relational events that compose the organism-environment field affects all other parts of the field (Woldt and Toman 2005: 84)

As indicated previously, the film does not move straightforwardly from an urban to a rural environment. There is a brief sequence that begins at $06^{\prime} 09^{\prime \prime}$ where the sheet is seen draped over bushes near a small copse of trees, shot first at a distance and then closer up, the camera panning across it. The film returns to the countryside at 15 '38" with a similar series of shots of the sheet hung between trees and in hedgerows, before returning to shots of domestic interiors, before moving at 18'00" to what appears to be a park, back to the same interior, and then at 19'00" to the final rural sequence, which begins with the sheet in the middle distance, lying against a hill. The film concludes with a number of shots of the sheet in a small valley, moving away from the viewer, as if filmed in stop-motion, before disappearing entirely. I mention all this to complicate 
the picture of the sheet in nature offering some kind of resolution, as suggested by the anonymous viewer of the film. In fact, the film's relationship to nature is more complex, and the function of the sheet in those final moments is more obscure and enigmatic. It retreats from our view, the camera static. The last seconds of the film are of the empty, motionless valley. Breakwell and Leggett pause on this shot for a short time, which provides a moment for the viewer to reflect on the relationship of the sheet, of the object, to the locations it has been placed within. To return to Gestalt Theory, Breakwell and Leggett disrupt the relation of figure and ground that serves within Gestalt Theory as a means of explaining how humans recognise objects that we see, how we distinguish between the object and its background. As Kurt Koffka writes:

The figure depends for its characteristics upon the ground on which it appears. The ground serves as a framework in which the figure is suspended and thereby determines the figure (Koffka 2001: 184).

Koffka emphasises the relationship between the two elements - it is only by the means of the ground that we can comprehend the figure. My interest here is not so much in the technical aspects of how we distinguish between figure and ground, but in the way that Koffka conceives the figure as being determined by a relation to the ground in which it sits. A classic example in the literature of Gestalt Theory of the figure/ground relation is of the ink blot or text as the figure against the ground of the white paper on which it sits. In Koffka's formulation, the ink blot is constructed as such by the ground. He writes:

An ink blot is by no means a perfectly homogenous area, and yet it has its unity and shape because of the discontinuity at its boundary (Koffka 2001: 148).

Breakwell and Leggett enter into this relation and disrupt it, the blank uniform ground becomes the figure. But, as Koffka indicates, the figure is constructed by its relation to the ground. The sheet allows for a slippage between figure and ground. This is most clearly visible in the opening sequence discussed above. Where Breakwell and Leggett conceal the bollard beneath the sheet, it is brought into focus, but when the sheet is removed and placed elsewhere in the frame, it recedes into the background.

Those concluding shots of the film, showing the sheet receding along the valley, and eventually disappearing from view, are reminiscent of a particular motif that appears frequently in avant-garde film which concerns the aftermath of the May '68 protests in France, particularly those made by the Zanzibar Group; that is, a retreat from the urban into nature. Made just two months after the events of May '68, Marcel Hanoun's L'été concerns a young woman who leaves Paris for a house in the Normandy countryside, and from there reflects on the events and her relationship to them. The film spends a lot of time showing the woman walking in nature, reading and relaxing; it presents the rural landscape as a space for contemplation and isolation. The brief shots of Paris, showing both her friends who remain in the city, but also some of the still graffitied urban environment, present the situation there as still febrile, chaotic and uncertain. The film's relationship to the political events is ambiguous, and the protagonist vacillates between feeling as though she should have stayed in Paris and expressing the necessity of her escape from it. What's key in the context of discussing Sheet, though, is precisely that the film presents that necessity of escape into nature in the immediate aftermath of May ' 68 , as though there is a compulsion to retreat, but also a compulsion to represent that retreat in film. This motif is replicated in the Dziga Vertov Group's Un film comme les autres, also made in 1968. The film features a group of students and workers, their faces largely occluded, sitting in a field on the outskirts of Paris, 
discussing the recent events of May '68. This footage is intercut with verité scenes of the protests. Godard and Gorin present a more explicitly political version of the movement from the chaotic urban scenes of protest to the measured pastoral environment that Hanoun shows in L'été. It is also key that the environment of the film is very close to the edge of Paris, at certain points the camera pulls back to show large modern blocks of flats near to where the protagonists are sitting; in Un film comme les autres, the revolution is very nearby, close enough to almost grasp, but still just unreachable, it seems, bogged down by the very discussion that the students and workers are having which concerns how to act, what to do. The natural environment that they are in, then, represents in its proximity to the urban, the uncertainty of the immediate post-' 68 moment, where a combination of the feeling that everything is possible, and everything has been lost seem to exist simultaneously.

Within this context of the retreat into nature in the wake of May '68, one might also consider Pierre Clementi's La révolution n'est qu'un début. Continuons le combat, and films made by Philippe Garrel during this period, but I want to point to one other, more abstruse example of this motif: Daneil Pommereulle's 1969 film, Vite. Filmed in Morocco in barren, rocky terrain, the film takes on a much wider-scale, more performative, angry and embodied response to the events of the May ' 68 protests, though one which feels much more distant from them, and which contains no images of Paris or of protesters directly. Filmed with much wider angles and including then state of the art shots of the night sky and the moon, Vite chastises the revolutionaries for their failure, and the indifferent sky and the endless rocks amplify this sense of desperate loss. In this terrain, a man carries a boy on his shoulders down sheer slopes and past pools of stagnant brown water. Rather than the pastoral spaces of L'été and Un film..., Vite shows a retreat into a bleak and hostile nature, an empty, lifeless void that swallows up anger and revolutionary momentum. Nicole Brenez makes a comparison to the work of Jodorowsky, writing that:

Daniel Pommereulle's Vite, a dance of execration during which the artist travels through deserts and otherworldly places symbolically opposed to the West, in search of gestures, rhythms, connections and sensations severed from any rationalist roots (exorcism, repetition, discontinuity, access to the impossible). Had Rimbaud made films in Abyssinia, he would have shot Vite. In Vite the body of the artist is a completely political organism, vomiting colonization (Brenez 2005).

What, then, should we make of the political content of Sheet, which similarly mixes the retreat into nature with shots of the urban environment, including shots of Paris? I would argue that it is possible to see a link between the French films made in the aftermath of May '68 and how Breakwell and Leggett construct their film. It is as though they have taken the impulses of those filmmakers and pushed them into a more abstract and structural realm. Vite, L'été and Un film... present the audience with characters who are outside of the site of direct action, they are elsewhere, and even in the two films which show Paris either during or in the immediate aftermath of protest, it's clear that those images are shown in contrast to what is happening to the protagonists of the films. The films themselves are spaces for reflection on the impact on the thoughts, the speech and the bodies of those who took part in the events. The films all occupy a distinctly pessimistic view of what happened - there is little sense in them (Clementi's La révolution... may be an exception) that further direct action will be successful or meaningful, and indeed these films prefigure a lengthy period of introspection on the left, as well as in some senses anticipating the political concerns 
and actions of later protest groups. The presence of the sheet in Sheet can be seen as a spectral trace of those protagonists, and the veering between urban and rural in the film as a re-enactment of the events of those films, and of the protests and the period of reflection that followed them. It is possible to see the ghostly presence of the sheet, both in its urban context and in the rural as being an elegy for those political movements, their failures and their consequences.

In several sequences, Breakwell and Leggett show crowds, and the way in which those crowds interact with the sheet. In the first of these, which appears to be filmed near Breakwell's home near Smithfield Market in London, a small crowd is gathered on one side of the road, opposite a branch of Barclays Bank. They are shown briefly amongst a series of shots of the sheet sliding off a roof, falling to the ground and being pulled into a window, that is, of the sheet in movement. The shot of the crowd is enigmatic, the reason for their presence unclear, and they are filmed at a distance where they are anonymous. Subsequently this same crowd is shown moving slowly out of the frame, along a side street.

Later, during a sequence that takes place at an art opening or party, the crowd are filmed from the shoulders down, their faces invisible beyond the top of the frame, anonymous, their voices audible but undifferentiated, no words are distinguishable in the audio. The sheet is shown alternately held, perhaps by the same figure, rolled or bundled under their arm, draped across their back like a shawl, clutched to their chest, and then abandoned, huddled or crumpled in corners and against walls. By moving between these two states, Breakwell and Leggett seem to imply some unstable relationship between the sheet and the person who holds it, as though it is repeatedly picked up and then discarded. Again, the crowd's presence is enigmatic, though voices can be heard on the soundtrack, individual words or conversations cannot be discerned, and the people we see are largely static.

Later still, the sheet is filmed from a high angle, placed on the ground in a crowded square. The people moving through the square indifferent to it, mostly moving around it, occasionally stepping over or onto it to get by. These crowds in the film are seemingly empty of direction or clear purpose, and the presence of the sheet among them uncannily emphasises that purposelessness.

The experience of watching Sheet is of a constant push and pull, a vacillation between the planned and the improvisatory. Discussing a series of paintings he made while artist in residence at Cambridge University, Breakwell says:

I was moving along a path from chaos, using intuition, chance, accident and illogical methods. Constant change, destruction and reworking were all part of the process. [...] Arriving eventually at an end product which was neither definitive nor proven, but deliberately ambiguous and open to interpretation by the spectator (Breakwell ND).

37 Breakwell's working methods emphasise an aleatoric approach that deliberately seeks to avoid fixed meaning and interpretation. The American critic and filmmaker R. Bruce Elder has written extensively on what he sees as a pernicious tradition within art criticism which aims to limit the meaning and experience of artworks to a purely discursive or linguistic set of interpretations. He writes that:

Some are troubled that much poetry develops from silly notions and that its statements are announced with embarrassing intimacy. Art has a strange, primitive appeal. The notions that inspire artists to make their work are sometimes silly, but they represent, in however distorted a form, a connection with a tradition far older 
- and, we might hope, stronger - than modernity, and their art draws strength from such ideas. Many commentators yearn to tame art's unruly power by turning it into a form of assertoric discourse. They want to convert the unruly, raw, and strange aesthetic experience into a cognitive experience, to flatten it into a form that modernity might validate (Elder 1998: 4-5). the meaning of a work of art within a purely textual interpretation. The improvisatory and performative nature of Breakwell's working methods necessarily allow for this expanded mode of interpretation. Of Stan Brakhage's work, Elder writes:

Often, he works with a cluster of forms for a while and then leaves that set of images behind and takes up another cluster. His films often seem, in consequence, to be made from a series of discrete phrases (presented once or several times); they do not build smoothly and continuously toward a dramatic climax, nor do they conform to the grande ligne of traditional musical composition. Instead, they appear as a series of fresh, new events (cf. the Steinian and Jamesian sense of the continual coming-on of novelty) that only the energy of immediate perception can hold together in a unity, and even the speed of perception can keep them united only temporarily (Elder 1998: 451).

to me that this quotation speaks to the way in which the affect of watching Sheet, the mesmeric qualities that Roger Hammond alludes to in his discussion of the film, emerge as a combination of the planned and the improvisatory. The cluster of sequences that Breakwell and Leggett employ both gesture towards a unity (of object, of framing, of location), but also away from any sense of absolute coherence.

I wish to conclude this piece by discussing Sheet alongside Robert Fulton's Street Film I, which bears a number of similarities to Breakwell and Leggett's film. In Street Film I, the first of a sequence of films, Fulton follows a piece of discarded newspaper as it is blown around the streets of Chicago. Also filmed in black and white, Street Film I exhibits the same tension between narrative and the anti-illusionist impulse that Sheet does, and the piece of newspaper takes on the same animus, the same sense of uncanny purpose that the sheet does. Fulton's object is much more information-dense than the sheet, displaying text and images on both sides (Fulton sees the piece of newspaper as a metaphor for the shift between what he calls hard information and soft information), and his encounter with it is more random as he follows the scrap of newspaper wherever the wind takes it. Just as Breakwell and Leggett's sheet is reshaped and deformed throughout their film, Fulton's newspaper becomes crumpled, worn away and ripped as the film goes on, and indeed it undergoes a permanent transformation that Breakwell and Leggett's sheet does not. The newspaper becomes utterly changed where the sheet is always capable of returning to its pristine, flat origin. We might say that Fulton is concerned with the deterioration of the object in real time, whereas Breakwell and Leggett are concerned with its permanence and suppleness. Despite these differences, both films have that improvisatory quality, both share a key component as their chosen object interacts with the environment around it. In both, that interaction is a structuring device and the means through which the possibility of narrative enters the frame.

41 I began by offering two contrasting interpretations of this film, one which saw in the embodied presence of the titular sheet something redolent of death and of man's relationship with nature, and the other which saw the film as a structural work, but one whose rhythms and repetitions induced and mesmerised the viewer. As I have argued, it is not the case that either one of these interpretations is more valid than the 
other. In fact, the film occupies a specific territory in which both are simultaneously true. There is a hallucinatory quality to watching Sheet. But one cannot also avoid questioning and examining the presence of the sheet, the object, in its various orientations, draped, wrapped, laid flat, hung in its environment. As I have also argued, the film reconstitutes a particular movement that we see in the films that immediately followed the events of May '68, from the urban to the natural environment, and constituting the natural environment where one trades the ability to act for the ability to reflect. By employing the absolute blankness and indifference of the sheet in their film, Breakwell and Leggett allow for these multiple entry points into it. It is a film which reflects the political, artistic and conceptual anxieties of its time, but also one which, in the way that it triangulates the two versions of the avant-garde film that Peter Wollen defines, resonates with contemporary debates about filmmaking and politics.

\section{BIBLIOGRAPHY}

\section{Filmography}

Clementi, Pierre. La révolution n'est qu'un début. Continuons le combat. Zanzibar Films, 22mn. 1968.

Dziga Vertov Group. Un film comme les autres. Anouchka Films. 103mn. 1968.

Hanoun, Marcel. L'été. Prod. Marcel Hanon. 64mn. 1968.

Leggett, Mike and Breakwell, Ian. Sheet. 22mn. 1970.

Leggett, Mike and Breakwell, Ian. 'Notes Concerning 'Sheet'. ND: http://

www.mikeleggett.com.au/sites/default/files/BFVASCIMG_0115.JPG

Le Grice, Malcolm. Berlin Horse. 7mn. 1970

Pommereulle, Daniel. Vite. 33mn. 1969.

Snow, Michael. Wavelength. 45mn. 1967.

\section{Secondary sources}

Breakwell, Ian. 'Ian Breakwell Conference Audio Recordings.' 24 September 2007. https:// www.tate.org.uk/context-comment/audio/ian-breakwell-conference-audiorecordings\#open 243037

Brenez, Nicole. 'Improvised Notes on French Expanded Cinema. Millennium Film Journal 43/44 (Summer/Fall 2005), Paracinema/Performance. http://mfj-online.org/journalPages/MFJ43/ Brenez.html

Elder, R. Bruce. The Films of Stan Brakhage in the American Tradition of Ezra Pound, Gertrude Stein, and Charles Olson. Ontario: Wilfrid Laurier Press, 1998. 
Gidal, Peter and LeGrice, Malcolm. Structural Film Anthology. London: British Film Institute, 1978.

Hammond, Roger. 'SHEET'. London Film-Makers' Co-operate Catalogue 1972' In Shoot Shoot Shoot: The First Decade of the London Film-Makers' Co-operative 1966-1976. 2002: 4. https://monoskop.org/ images/c/c4/Shoot_Shoot_Shoot_The_First_Decade_of_the_London_Film-Makers_Cooperative_and_British_Avant-Garde_Film_1966-1976.pdf

Koffka, Kurt. Principles of Gestalt Psychology [1935]. London: Routledge, 2001.

Krauss, Rosalind. 'Grids.' In The Originality of the Avant-Garde and Other Modernist Myths. Cambridge, Massachusetts: MIT Press, 1986. 9-22.

Leggett, Mike and Breakwell, Ian. 'Notes Concerning 'Sheet'. Ian Breakwell Files, AHRB Author0000-00-00T00:00:00ACentre ND.

Michelson, Annette. 'Film and the Radical Aspiration.' In P. Adams Sitney, ed. Film Culture Reader [1970]. New York: Cooper Square Press, 2000. 404-421.

Payne, Joy L. Reel Rebels: The London Film-Makers' Co-Operative 1966 to 1996. London: AuthorHouse UK, 2015.

Rees, A.L. 'Locating the LFMC: The First Decade in Context.' 24 November 2016. https:// lux.org.uk/writing/locating-the-lfmc

Rodowick, D.N. The Crisis of Political Modernism: Criticism and Ideology in Contemporary Film Theory. Berkeley: University of California Press, 1988.

Woldt, Ansel L. and Toman, Sarah M. Gestalt Therapy: History, Theory, and Practice. London: Sage Publications, 2005.

Wollen, Peter. 'The Two Avant-Gardes.' 23 February 2018. https://www.versobooks.com/blogs/ 3634-the-two-avant-gardes

\section{NOTES}

1. See Fulton's discussion of the film as part of the Screening Room series (https:// www.youtube.com/watch?v=EqJ7WeeFgRs)

\section{ABSTRACTS}

This article examines Mike Leggett and Ian Breakwell's short film Sheet. Though little scholarship exists on Sheet, the enigmatic quality of the film and the sheet that gives it its name has given rise to a number of contrasting interpretations. The article discusses two opposing accounts of the film, one which sees it as being a film haunted by the ghostly presence of the titular sheet, and which contains some form of narrative and resolution, and one which sees it as an example of structural film, characterised by repetition and formal concerns. I align these two interpretations with Peter Wollen's article on the two avant-gardes in contemporary film and argue that Leggett and Breakwell's work, through their improvisatory approach, triangulates Wollen's distinction, and allows both interpretations to be simultaneously true. In addition, I 
discuss the way in which the film re-examines a theme found in filmmaking in the immediate post May ' 68 moment, of characters moving from the urban to the rural. As such, the film can be seen as expressing the anxieties and concerns of that period, both political and artistic.

Cet article analyse le court métrage Sheet de Mike Leggett et Ian Breakwell. Bien qu'il existe peu d'études sur Sheet, la nature énigmatique du film et du drap qui lui donne son nom a donné lieu à un certain nombre d'interprétations très contrastées. L'article aborde deux interprétations opposées du film, l'une qui considère qu'il s'agit d'un film hanté par la présence fantomatique du drap du titre, et qui contient une certaine forme de récit et de résolution, et l'autre qui le considère comme un exemple de film structurel, caractérisé par la répétition et les préoccupations formelles. Je rapproche ces deux interprétations de l'article de Peter Wollen sur les deux avant-gardes du cinéma contemporain et affirme que le travail cinématographique de Leggett et Breakwell, par son approche improvisée, fait la synthèse de la distinction de Wollen et permet aux deux interprétations d'être simultanément vraies. En outre, je me penche sur la manière dont le film réexamine un thème que l'on retrouve dans le cinéma au lendemain de Mai 68 , celui des personnages qui passent de la ville à la campagne. En tant que tel, le film peut être considéré comme l'expression des angoisses et des préoccupations de cette période, tant politiques qu'artistiques.

\section{INDEX}

Keywords: Leggett Mike, Breakwell Ian, film, experimental film, repetition, avant-garde, May '68 Mots-clés: Leggett Mike, Breakwell Ian, film, film expérimental, répétition, avant-garde, mai 68

\section{AUTHOR}

\section{KIERAN DEVANEY}

Kieran Devaney is a writer and independent scholar based in Sheffield. Recent publications include the short stories 1992 - 1998 in The Invisible Collection (Nightjar Press) and Sitcom in Best British Short Stories 2019 (Salt), as well as the essay 'Contradiction, Incongruity and Fragmentation: Political and Avant-Garde Compromise in the Work of Alan Burns', which appears in British AvantGarde Fiction of the 1960s (Edinburgh University Press). Contact: kierandevaney [at] hotmail.com 